\title{
Maria Dada
}

\section{QUEERING GEOGRAPHIC INFORMATION SYSTEMS}

\begin{abstract}
What's the relationship between GIS and the political subject? In an effort to address this question, this paper traces the movement from the map to GIS. The map is shown to be the performative utterance of the state, one that supports its national discourse and narrative. GIS, on the other hand, is shown to be a device of neoliberal governmentality, its non-representational economic practices, divided discourse and subjectivities. Despite the seemingly hopeless situation surrounding GIS, however, certain simulation and modelling practices are attempting to construct subjectivities out of economic neoliberalism's fractured narratives. They do this by reading meaning into otherwise mathematical datasets and models. These practices could form a basis for queering GIS.
\end{abstract}

APRJA Volume 8, Issue 1, 2019

ISSN 2245-7755

CC license: 'Attribution-NonCommercial-ShareAlike'. 


\section{Introduction}

The field of cartography as the academic study of the history and meaning of mapmaking is in decline, or "is dead" ("Cartography Is Dead" 4), according to Denis Wood, one of the foregrounding figures of critical cartography. It is being ingested into what might, on the surface, seem like a continuation of the discipline but in fact is not. The practice taking over from cartography is that of digital modelling.

Nonetheless, many critical cartographers including Wood, find no reason to bemoan this loss. They might even celebrate it. "Thank God" ("Cartography Is Dead"), proclaims Wood (4). Contrary to what one might imagine, the map is a relatively recent practice dating back only to the $1500 \mathrm{~s}$. Its lineage coincides with the emergence of the disciplinary sovereignty and the state's right to political violence, what political theorist Archille Mbembe would call necro-political power.

The map in that sense is a performative utterance of state territory. Without a map, the state would not be conceived of as a thing, a map-able object with borders and edges, "state borders are brought into being through mapping" (The Power of Maps 45). The map becomes the icon or as historian and political scientist Benedict Anderson claims the logo of the state and this icon with its definite borders erases the lineage of its construction.

As critical geographers such as Paul A. Longley and Matthew W. Wilson affirm, it is not that the map was transformed into a digital map but rather that digital modelling as a practice cannibalised the remnants of a dying tradition for its own gains (Longley; Wilson). Accordingly, the trajectory of the move from mapping to Geographic Information Systems (hereafter GIS) is not a linear progression but rather a disruption and displacement of the map by the model. In fact, most applications that later become the digital map didn't have a map to begin with. They were created in order to forecast population information for the user by city officials, planners and businesses. The so-called maps, such as the OXAV and SYMAP were complex and had their own symbols with an accompanied user manual that explains how they were to be interpreted. None had a drawing of the terrain or land.

The following paper extends this discourse by showing the relationship between subjectivity and GIS, a relationship that is missing from various accounts of critical GIS which centre on critiquing statistical modelling for its alleged positivism as does Stan Openshaw, for instance, in his 1991 article, "A view on the GIS crisis in geography". Rather than interpret digital modelling as strictly a quantitative method, as Openshaw regarded it, this paper reveals its performativity, one that is remarkably different from that of the map. The two are similar in that they not only describe but rather construct territories, understood as extension of sovereign power, however with modelling, these territories are no longer bound to the land, they are no longer strictly spatial but rather penetrate the psychology, behaviour and even molecules of those subjected to its power.

Digital mediatheoristssuchasAlexander Galloway and Bernard Stiegler, following Gilles Deleuze in the article "Postscript to the Societies of Control," have interpreted this territorial permeation by digital media more generally as a cause for the disarmament of the political subject, the subject's endless division into manipulable units of data or code. Deleuze himself sees the individual subject transformed into a dividual, endless units of data subtracted from individuals and their bodies, he explains, "Individuals have become 'dividuals,' and masses, samples, 
data, markets or "banks'”(5). In The Exploit Galloway and Eugene Thacker also suggest that the political subject of digital media is divided into atomic units that make up part of a larger network. Paul B. Preciado, on the other hand, sees this type of control modulating subjectivities at a molecular level through pharmaceuticals. GIS could, therefore, be seen to follow this logic and further dismantle the political subject into units of data through its use of statistics and cognitive psychology. Contrary to this reasoning, however, this paper shows that GIS or digital modelling in fact offers a way to potentially unearth a radical political subject.

With that in mind, this paper is divided into five sections. Section one begins with the problem set out by Deleuze in "Postscript to the Societies of Control." It relates his article to Michel Foucault's work on neoliberalism in The Birth of Biopolitics, setting the scene for section two where the link between Deleuze and Foucault's ideas around subjectivity are brought closer to the economic practices of digital modelling through the work of Philip Mirowski.

The remaining three sections delineate the movement from mapping to GIS within the fields of cartography and geography more specifically. The key difference between GIS, which is largely based in non-representational economic practices, and maps, which is based in narrative, is outlined in section five. Finally, the conclusion touches on the ways in which GIS could potentially reinstate a form of political subjectivity and retain a critical dimension.

\section{Deleuze after Foucault}

Deleuze's article "Postscript to the Societies of Control" references and extends Foucault's work, primarily Discipline and Punish, but also includes Foucault's work on biopolitics and political economy. Foucault centres much of his later publications and lectures on the genealogy of power, or what he calls the knowledge-power nexus. In Discipline and Punish he shows the movement of power from what many, including political theorist Achilles Mbembe, have referred to as necropolitical power; the power of the sovereign king to take away life as a form of punishment for transgressing his law, to regimes of discipline or disciplinary society, where control is no longer based in the threat of death. Instead, disciplinary society is engaged in the self-disciplinary techniques of discourse, the institutions and surveillance mechanisms similar to the architecture of the panopticon as described by Jeremy Bentham.

However, according to Deleuze, the institutions that Foucault describes in Discipline and Punish, are in crisis or in perpetual need of reform. They have been replaced by "a new monster" (Deleuze 444). Disciplinary control is no longer positioned at the institutional level but has rather been internalised by each subject who as a result is no longer a subject but a 'dividual', a term Deleuze shares with Félix Guattari. In other words, it is no longer the architecture of the school, the barracks, the prison that keep us from misbehaving. Control society works at modulating subjectivities at a more granular level through mechanisms that theorists, including Galloway, have interpreted to resemble those of digital media.

Actually, Foucault, in his lectures on The Birth of Biopolitics, delivered around thirteen years prior to the publication of "Postscript to the Societies of Control," was beginning to touch on some of these ideas. His account, described in the remainder of this section, offers an alternative interpretation to Deleuze's notion of the dividual which informs its relationship to digital modelling and GIS.

He dedicates the lectures to highlighting 
the multiplicity of shifts within power or the art of government discussed above, the movement from punitive sovereignty, or necropolitical techniques of power, where the state assumes the role of what Foucault describes as "a cold monster" to what he describes as a more 'reasonable' form of power.

Under necro-political art of government the king was able to punish and kill while being answerable to no-one but the divine laws of God. Breaking the divine laws of God would force the sovereign to step down. However, as the mode of power shifts so too do the laws that govern it. If the necro-political king is only accountable to his subjects in relation to the divine laws, the sovereign of governmental reason is not accountable at all but rather limited by nature.

Under what Foucault refers to as the 'reasonable' raison d'état the sovereign has to negotiate their power with that of nature and its laws. The paradox, of course, is that one cannot reason with nature. It is in a sense the condition and the limit of rationality. Therefore, the laws of nature are supposedly imposed on the state. The latter is, of course, the fallacy that Foucault is exposing in the lecture.

In other words, the laws of nature, which are imposed on the state of the raison d'état, operate differently to the laws of God. Foucault explains,

To say that there is a de-facto limitation of governmental practice means that a government that ignores this limitation will not be an illegitimate, usurping government, but simply a clumsy, inadequate government that does not do the proper thing. (10)

Put differently, breaking with the internal limitations of governmental reason will not render it illegitimate because these limitations are no longer juridical. Natural laws are beyond the control and interpretation of any sovereign, man or subject.

Now as it happens the most effective form of rationality, which is used in order to calculate and make sense of the selflimitation of governmental reason, is political economy or the supposed natural laws of the self-regulation of the market. Foucault continues,

the intellectual instrument, the form of calculation and rationality that made possible the self-limitation of governmental reason as a de facto, general self-regulation [...] is political economy (13).

In fact, as he himself admits, all of Foucault's final lectures on biopolitics need to be understood through the lens of political economy and its tools such as economics. It is the intellectual apparatus born out of the raison d'état to enrich the state against its enemies.

Political economy, nonetheless, determines the success or the failure of government but does not illegitimate it. Governments can simply be mistaken by ignoring the new laws of nature, the laws of the market. A bad governor is not wicked but ignorant. Ignorance does not dissolve a government. The relationship between truth and self-limitation, however, is not about wisdom of rule such as that of the Machiavellian prince. In place of the wisdom of the prince, governments rely on economic experts "whose task is to tell the government what in truth the natural mechanisms are of what it is manipulating" (17).

It is the judgement of governmentality on success in opposition to legitimacy that pacifies the political subject and turns them into dividuals in Deleuze's terms. The issue, the reason governmentality is no longer judged for its legitimacy, and what troubles 
Foucault, is that sovereignty and the law are no longer set in relation to citizens as subjects. The market, and its supposed natural laws, are now the medium between sovereign and subject.

The only means for the sovereign to govern its subjects is through the market and its economic experts. However, economics, the discipline of political economy that aims to understand the market remains agnostic to narrative, meaning and representation. It, therefore, reduces the subject into a market actor at best or a multitude of divided economics units in Deleuze's view, the dividual. The subject, through an economic understanding of the market, is nothing but a multitude of cogs in the system never united under a single rebellion against the king for instance.

\section{The emergence of digital modelling}

The next section will look at the emergence of digital modelling within economics as neoliberal governmentality's means of making sense of, and therefore governing, the market by translating each of its elements into computable units of data for use in mathematical modelling or statistical mechanics.

According to Philip Mirowski, prior to the Second World War the rational choice, mathematical model-based economics that engulfs our current economic system was not the dominant discourse. Donald Mackenzie agrees,

Economics had developed in the eighteenth and nineteenth centuries predominantly as what the historian of economics Mary Morgan calls a "verbal tradition." Even as late as 1900, "there was relatively little mathematics, statistics, or modelling contained in any economic work" (Mackenzie 7).

In fact, there wasn't a particular dominant form of economics. Mirowski insists, "there was no dominant orthodoxy in American economics prior to World War II, although the indigenous strain of American Institutionalism held some key strategic outposts at Columbia and Wisconsin" (Mirowski, Machine Dreams 190). Institutionalism was of the view that institutions played a major role in shaping the markets and encouraged the broader understanding of their role in such a process.

After the second world war in the 1950s the rise of the American economic model of laissez faire and the increasing availability of data fortified the link between mathematical modelling and the market. The relationship between the two fields was also influenced by the burgeoning field of Operations Research (hereafter OR) and the impact of the cold war's reinforcement of technical innovation.

Mirowski's claim is that mathematical and later digital models developed during the second world war fuelled the highly specialised new discipline of OR. OR is regarded as the predecessor to most computing disciplines. It is influenced by early inventors of the computer such as Charles Babbage. It was mostly invested, however, in the analysis and management of market-based decisionmaking, including but not limited to rational choice theory, a system for simulating or modelling social and economic behaviour within a market or market-like system, how market actors make market-based decisions. $\mathrm{OR}$ is often referred to as decision science or management science.

It is key in spawning academic disciplines such as game theory, cybernetics, cognitive science and even artificial intelligence all of which employ some form of digital and mathematical model. 
Modelling allows these disciplines, and decision science more generally, to make economic sense of any element in a market or market-like system regardless of what that element is or how small it is. In other words, digital modelling is a means of determining the state of a market-like system through mathematical non-representational methods, methods that are not based in narrative or meaning but rather elements, actors, cogs and perhaps dividuals.

The next few sections will look at how the map, more specifically, as an apparatus of governance, has been transformed as a consequence of digital modelling, how global GIS comes to take over from the map as the new apparatus for a new style of governance, one that is based in non-representational economic principles.

\section{Necropolitics and the map}

This section will explore the significance of the map, and consequently the discipline of cartography, as an apparatus of necropolitical power, the power of the sovereign to take away life as a form of punishment for transgressing his law. It will show that necropolitical regimes are interested in maps in order to enforce taxes, voting patterns and population control and management. Maps, in that sense, are the performative utterance of sovereign space as the playing field for governmentality and power.

As mentioned in the introduction and as critical cartographers such as Denis Wood and James Scott have made evident, the map is a relatively recent apparatus dating back only to the 1500 s. Its lineage coincides with that of the sovereign and state power. Prior to the 1500s few maps were created in the vein in which they were drawn under necro-political rule, to assign territory and control borders. Most maps prior to 1500 , including the oldest map that remains in existence, the clay "Babylonian world map" dating back to the 6th century $\mathrm{BC}$, were created for cosmological speculation rather than territorial redistribution. The map as a measure and distribution of resources didn't begin until after the 1500s with examples of the Habsburg emperor Phillip II of Spain who commissioned surveys of his various possessions in differing territories.

As a matter of fact, very few maps have survived from the Greek, Roman or Medieval era. There are a lot of descriptions of maps and how to create them, including Ptolemy's Geography and the various different succeeding comments on it. However, what we know as the Geography was more often referred to as the 'cosmographia'. Ptolemy and his commentators such as the medieval scholar Al Khawarizmi intended to use maps in order to speculate on the known world. They did not survey it with the aim of dividing it up and creating zones.

In a sense, as Scott proclaims,

The premodern state was, in many crucial respects, partially blind; it knew precious little about its subjects, their wealth, their landholdings and yields, their location, their very identity. It lacked anything like a detailed 'map' of its terrain and its people. (Scott 2)

That is not to say that there weren't any map-like drawings conceived of to manage particular problems such as plans and drawings of cathedrals. Many of such drawings served as a form of inventory but none surveyed the many details of the land as the topographical maps by the time they were completed in the 20th century. They were more interested in the plan of a restricted area for a specific use. In many cases when map-like drawings did exist, such as the 
Arabic naqshah, these graphical representations were not referred to as maps. In that sense, they are more akin to paintings. The structure of the modern map is fairly recent and it coincides with its paradigm of use.

Contemporary maps, that demarcate territory, didn't begin to appear until after the 1500s. Most heads of state around that time continued along the direction of mapping space, infrastructure and land under the sovereign's control. For instance, JeanBaptiste Colbert, a minister of home affairs under Louis XIV, ordered the surveying and mapping of the whole of France in 1663.

The most extensive cartographic project occurred in France after the end of the conflict between Spain and France following the Treaty of the Pyrenees in 1659, a treaty that results in a joint commission to set the boundary between the duelling states. The boundary between Spain and France was instated as the first official boundary in Europe. Other notable boundaries were the result of the cartographic work of the Cassini family over four generations, the first trigonometric map regarded as a topographic land survey. Not to mention the fortification of the Sébastien le Presetre de Vauban country. Any institutional history book would point to multiple examples from European history and beyond of sovereigns ordering the surveying of their territory. Mapping was a key proponent of what Foucault would call disciplinary state sovereignty.

What is being proposed here is that the lineage of the emergence of the modern map coincides with the lineage of disciplinary society and necropolitical power. The bigger claim, however, is that the map is an artefact, a mode of writing, technology, that brings the state's territory, and therefore the extension of its power, into being. In other words, the map is responsible for the state's existence and vice versa. The state then goes on to affirm the map by insisting that it is a mere representation of the earth's surface, hiding the performativity of the process of its own creation. In this sense, maps are an ontological claim of the existence of the state. The next section will delineate further the relationship between maps and the territory they demarcate.

\section{Territory}

The geographer Stuart Elden dedicates his monograph The Birth of Territory to showing that the notion of 'territory' refers less to the land but rather more generally to the measure and extension of sovereign power. As such its meaning is mutable and based on the varying forms of sovereignty that appear throughout history. He claims,

Territory is not simply land, in the political-economic sense of rights of use, appropriation, and possession attached to a place; nor is it a narrowly political-strategic question that is closer to a notion of terrain. Territory comprises techniques for measuring land and controlling terrain. Measure and control-the technical and the legal- need to be thought alongside land and terrain. (Elden 322-323)

The technical that Elden is referring to is synonymous with mapping techniques which, as I will show, later become modelling techniques taking over from the map's form of measurement. Maps allow a certain, representational grasp of the materiality of nature, its mountains, deserts and tundras, not to mention the way maps were used to impose divisions on the colonised. They delineate and sustain territory through national state narrative. 
At the moment, however, the state's stronghold on the map is weakening because the structure of the state and its institutions, as Deleuze professes, "is in crisis" (Deleuze 444). The state has not been eradicated, as such, but rather qualitatively transformed due to global geo-economic conditions and the neoliberal governmentality that has emerged. State territories have been reconfigured in response to global trade influence. These contemporary conditions do not abolish or confine state territories but rather produce new state spaces that are entangled in trade relations and new forms of competition. The institutional questions that concern the state no longer converge and in that respect as Neil Brenner makes clear in New State Space it might be misleading to speak of 'the state' as such. Indeed, this is Henri Lefebvre's point when in the 1970s he discusses the 'explosion of spaces,' a concept then only in its infant stage. The institutions, regulatory agencies and markets that comprise the state are no longer easily demarcated and in that sense are somehow in crisis.

The representational scalar vocabularies of the map have been ill equipped to describe the new geo-economic interdependencies, interdependencies that have come to demand a new style of governance where the market and economists intervene at every level. Consequently, the discipline of cartography becomes more detached from the practice of mapmaking in the traditional sense of drawing maps with pens, paper sheets and hand drawn projections. There is a decline in cartography in favour of a more economics-based and consequently nonrepresentational model and this logic runs parallel with the restructuring of territory and perhaps the state altogether.

In the digital era map making is more readily referred to as geographic information systems (GIS), surveying, city planning or real estate planning. Even drawn out fields such as psychology and biology have become more akin to 'mapping' than cartography. The model, in its economic sense but also in a wider sense of mathematical modelling, expands the notion of territory without excluding previous formations of it. The difference between the two is a matter of temporal and geometric scale and the way that neoliberal governmentality operates at these varying scales.

Modelling is not restricted to physically observable phenomena such as Newtonian physics and geometry. For instance, the weather can be modelled in what is referred to as real time. In the same vein, modelling, stretches to cover many aspects of social and political life such as voting patterns, criminal offending patterns, the tax value of homes, bus routes, bike paths as well as consumer preference. And yet it doesn't exclude things like the modelling of farm land, roadblocks or other infrastructure. Mapping, on the other hand, operates only at the Newtonian scale, the observable and representational, and encompasses areas interpretable through signification and language, signs, semiotics etc. The next and final section will trace the lineage of GIS to show its links to economic practices.

\section{GIS}

The story of the digital map in the1960s coincides with the emergence of computer modelling techniques, social econometrics and the infiltration of these practices into the field of geography. However, creating maps with computers in those days required sophisticated graphical mapping applications which didn't mature until much later. Even before their advent, however, computers were still modelling data for urban analysis. 
In other words, the applications that later became the digital map didn't have a map to begin with. They were created in order to forecast population information for use by city officials, planners and businesses.

One of the first geographers to lay the grounds for the digital map was a scholar named Howard Fisher from Northwestern University. He founded the Laboratory for Computer Graphics and Spatial Analysis. Fisher began as an architect and then came to setting up a company that adapted factory methods to the creation of prefabricated houses only to see his company fail with the pressures of the Great Depression.

It was at Northwestern that Fisher appointed programmer Betty Benson to develop the Synagraphic Mapping System (hereafter SYMAP). Tensions were present between the mid-century cartographic community and Fisher's new practice of spatial analysis. However, for those wanting to see modelling enter the discipline of geography, the map was seen as a vehicle that would enable geography to rise and become a science.

Quantitative geography was quite different from its qualitative counterpart as it had more in common with that of economics or economic geography. So much was clear with the recruitment of William Warntz as associate director of the Laboratory of Computer Graphics and Spatial Analysis from his previous post as an economic geographer at Penn. He ended up working on the urban simulation routine called METROPOLIS which used SYMAP to create an animated cartography of Lansing, Michigan.

One of the first so-called digital maps was used to map urban blight in the Washington city of Spokane. The map looked nothing like a geographical map but was rather a graphical representation of population in the aid of control. Most of the research in early digital mapping which was later to become the now extensive field of GIS was

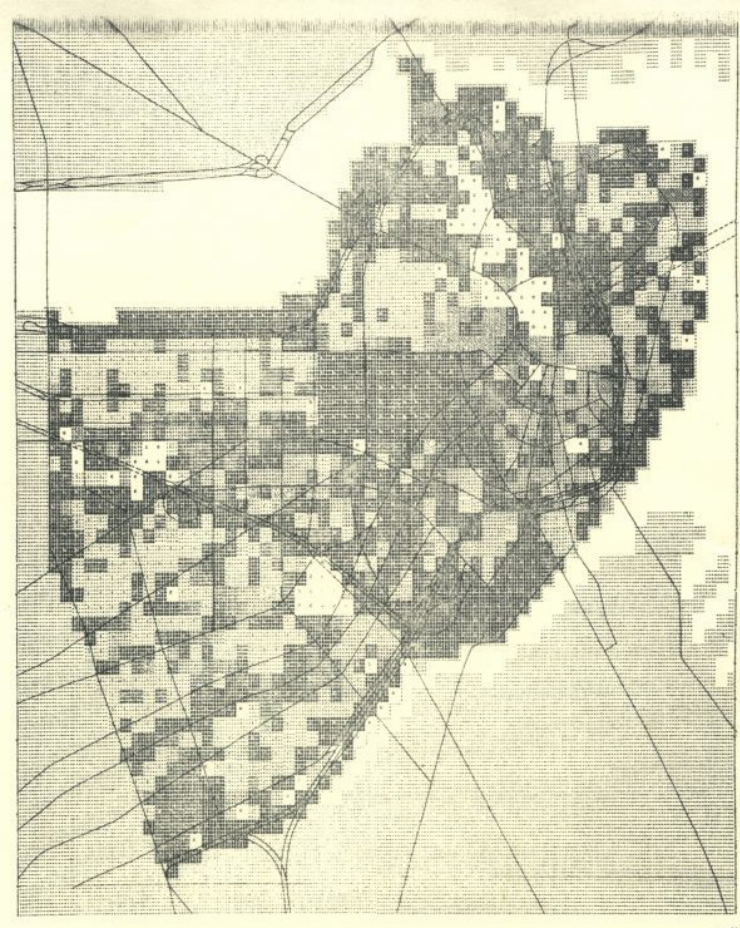

Figure 1: A map produced by Carl Steinitz while at MIT in the mid-1960s called "The Principle Local Activity of a Place."

funded by business groups such as the Ford Foundation. The so-called maps, such as the OXAV and SYMAP were complex and had their own symbols with an accompanied user manual that explains how they were to be interpreted. None had a drawing of a terrain or land.

It was only through the work of Warntz, his experience as an economic geographer and his work on urban simulation routines, not to mention the remainder of the money from the Ford Foundation that SYMAP's drawings began to resemble geographical maps. And even when this occurred it was only in order to simplify the display and reading of population data so that a layman would be able to interpret the results.

The point is that much of what is referred to as GIS is based in the mathematical modelling techniques that come out of economics and various forms of marketbased decision theory, techniques that are largely quantitative, non-representational 
and adhere to a particular style of governance. And yet, GIS, like its predecessor the map, remains the performative utterance of a territory that can only be known through the model itself, a model that is supposedly non-representational. As Michel Callon and Donald Mackenzie claim, despite being able to make do without the representational idiom, models remain performative within the world that constructs them.

\section{Conclusion}

A remarkable difference between maps and models is that maps as descriptors of the earth's surface contain graphical visualisations that rely on imaging hermeneutics and the application of signification or meaning. Simply put, they are comprised of signs, the lines of the borders as signifier to the territory as signified. The interpretation of the map is a function of power and society as it relates to the way the map is drawn. Nonetheless, its value as a representation creates a kind of regulative fiction where the becoming of state territory is sustained socially through national narratives.

In other words, the national discourse constructs and maintains the identity of the state as that which is acted out by the performative utterance of the map. The question of resistance becomes one of manoeuvring through normative frameworks.

Digital models, on the other hand, may have simulations, executions of the models, that resemble maps or take the form of representations and visualisations but primarily they are mathematical entities, quantifiable and statistical. They divide their subject into manageable units that are not primarily representational.

However, and this is what the paper will conclude on, this does not mean that they lack the capacity to generate narrative. Studies by computational media pioneer Fox D. Harrell show that there are alternative ways to engage computational modelling. With the help of computational and algebraic linguistics, Harrell aims to derive meaning from what is otherwise viewed as structural and numerical datasets, datasets that drive many computational models.

For example, with the Advanced Identity Representation (hereafter AIR) vatar Platform Harrell constructs a system that reveals patterns in various modelled virtual identities. AIRvatar helps reveal the meanings behind a system, and consequently its biases, of which model and dataset creators may or may not have been aware. As a platform it has been instrumental in the discovery of statistical patterns of race and gender discrimination in video games.

Harrell has also been looking into alternatives to economic modelling in social media, models that do not assume all actors to be motivated by economic decisions. In the online interactive game Chimera: Gatekeeper Harrell constructs a dataset that attempts and maintains the fluidity of the user's identity in relation to the changing context of the interactive narrative.

What Harrell's experiments show is that algebraic linguistics could be used to read meaning into the so-called dividual elements of data that models produce and manipulate. Doing so would enable a type of critique or resistance to the territorialisation by various model structures. A map describes only what is seen on the surface of the body of sovereign territory. Models on the other hand extend their performativity deep into the crust, tracing ecologies and patterns wherever they may be found. However, by reading meaning into these patterns and datasets there is no reason why critical GIS practitioners could not continue to construct an extensive critical discourse and practice. 


\section{Works cited}

Brenner, Neil. New State Spaces: Urban Governance and the Rescaling of

Statehood. Oxford University Press, 2006.

Callon, Michel. The Laws of the Markets. Blackwell, 1998.

Callon, Michel, et al. Market Devices. Blackwell, 2008.

Elden, Stuart. The Birth of Territory. University of Chicago Press, 2013.

Deleuze, Gilles. October: the Second Decade, 1986-1996. Edited by Rosalind E. Krauss, MIT Press, 1997.

Foucault, Michel. The Birth of Biopolitics Lectures at the College De France, 19781979. Translated by Michel Senellart, Palgrave Macmillan, 2011.

Lefebvre, Henri. The Production of Space. Translated by Donald Nicholson-Smith, Blackwell, 2009.

Longley, Paul A. "The Academic Success of GIS in Geography: Problems and Prospects." Journal of Geographical Systems, vol. 2, no. 1, 2000, pp. 37-42., doi:10.1007/s101090050027.

Openshaw, S. "A View on the GIS Crisis in Geography, or, Using GIS to Put HumptyDumpty Back Together Again." Environment and Planning A: Economy and Space, vol. 23, no. 5, 1991, pp. 621-628., doi:10.1068/ a230621.

MacKenzie, Donald A. An Engine, Not a Camera: How Financial Models Shape Markets. MIT Press, 2008.
MacKenzie, Donald, et al. Do Economists Make Markets?: On the Performativity of Economics. Princeton University Press, 2008.

Mirowski, Philip. More Heat than Light: Economics as Social Physics: Physics as Natures Economics. Cambridge University Press, 1995.

Mirowski, Philip. Machine Dreams:

Economics Becomes a Cyborg Science.

Cambridge Univ. Press, 2006.

Scott, James C. Seeing like a State How Certain Schemes to Improve the Human Condition Have Failed. Yale Univ. Press, 2008.

Wilson, Matthew W. New Lines: Critical GIS and the Trouble of the Map. University of Minnesota Press, 2017.

Wood, Denis, and John Fels. The Power of Maps. Routledge, 1993.

Wood, Denis. "Cartography Is Dead (Thank God!)." Cartographic Perspectives, no. 45, 2003, pp. 4-7., doi:10.14714/cp45.497. 